\title{
Efficacy of Soil and Foliar Application of Macro and Micronutrients on Yield and Quality of Mango cv. 'Dashehari'
}

\author{
Pankaj Kumar $^{1 *}$, A.K. Singh ${ }^{1}$ and S.C. Shankhdhar ${ }^{2}$
}

${ }^{1}$ Department of Horticulture, College of Agriculture, College of Basic Sciences and Humanities, G. B. Pant University of Agriculture and Technology, Pantnagar - 263145

(U.S. Nagar, Uttarakhand), India

${ }^{2}$ Department of Plant Physiology, College of Basic Sciences and Humanities, G. B. Pant University of Agriculture and Technology, Pantnagar - 263145 (U.S. Nagar, Uttarakhand), India

*Corresponding author

\section{A B S T R A C T}

The experiment was carried out at Horticulture Research Centre, Pattharchatta, G. B. Pant University of Agriculture and Technology, Pantnagar, district- Udham Singh Nagar,

\section{Keywords}

'Dashehari',

Mango,

Macronutrients,

Micronutrients,

Quality, Yield.

Article Info

Accepted:

17 September 2017

Available Online:

10 October 2017
Uttarakhand during the year 2015-16. The experiment was laid out in RBD (Randomized Block Design) with 10 treatments and 3 replications. The results showed that the foliar application of macro and micronutrients exhibited improvement in fruit set, fruit yield, quality and nutrient status of soil and leaf. The investigation has shown that the application of RDF(1000 g N: 750 g P: $1000 \mathrm{~g} \mathrm{~K})+$ NPK: 20:20:20 @ 1\% (2 spray: first-15 days and second- 45 days after fruit set) + foliar spray of $\mathrm{ZnSO}_{4} @ 0.4 \%+$ Boric acid @ $0.2 \%+$ $\mathrm{CuSO}_{4} @ 0.2 \%$ (2 spray at just before flowering and marble stage) was found very effective for increasing the yield ha ${ }^{-1}$ (22.82 tonnes), per cent increase in yield (197.41\%), fruit weight $(254.60 \mathrm{~g})$, fruit length $(10.86 \mathrm{~cm})$ and fruit width $(5.65 \mathrm{~cm})$. The content of

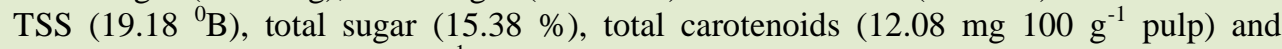
ascorbic acid (48.47 mg $100 \mathrm{~g}^{-1}$ pulp) were also increased with this treatment. Thus, it is concluded that the foliar application of NPK (20:20:20)@1\%+ $\mathrm{ZnSO}_{4} @ 0.4 \%+\mathrm{Boric}$ acid@0.2\%+ $0 . \mathrm{CuSO}_{4} @ 0.2 \%$ along with RDF (1000 g N: 750 g P: 1000 g K) may be adopted for improving the yield and quality of mango cv. Dashehari.

\section{Introduction}

Mango is the national fruit of India and it has developed its own importance all over the world. Being a useful and delicious fruit, it is a part of culture and religion since long time. Mango can be grown under both tropical and sub-tropical climate. It is originated from Indo-Burma (Myanmar) region (Vavilov, 1926; Popenoe, 1920). It occupies prime place in fruit crops and has largest area under fruit cultivation in India. Mango belongs to the genus Mangifera of the family Anacardiaceae. The genus Mangifera consists of 69 species and classified into two subgenus i.e. Mangifera and Limus and 11 uncertain position species (Kosterman and Bumpard, 1993). The cultivation of mango in India is as old as 4,000 years as reported by De Candolle (1883) and on the basis of writing by subsequent botanist it is 6,000 years (Hill, 1952). Mango is also called "King of fruits" 
because of it is rich source of nutrient, luscious, aromatic flavour, good amount of dietary fibre \& carbohydrates and a delicious taste in which sweetness and acidity delightfully blended. It is one of the most important fruits of India and besides delicious taste, excellent flavour and attractive fragrance, it is rich in vitamins A \& C. Mango fruit may be utilized at all stages of its development but generally used at mature stages. In India, it is grown on an area of 2.21 million hectare with annual production of 18.51 million tonnes having productivity of 8.37 metric tons per hectare during the year 2014 (Anonymous, 2015).

The productivity of mango is low at national level due to various factors such as indiscriminate use of chemical fertilizers, scanty use of micronutrients, alternate bearing, fruit drop, mango malformation, spongy tissue and susceptibility to major disease and pests (Iyer and Degani, 1997). An indiscriminate use of chemical fertilizers paved the way for deterioration of soil health and in turn affect trees with yield and fruit quality. Soil is the reservoir of macro and micro nutrients but with the advancement of commercial farming, more emphasis is given to production without taking care of soil health and eventually soil health deteriorates and production falls. The farmers are applying the nutrients mainly through soil application whereas; nutrients can also be applied directly to the site of their metabolism through foliar application. Major elements/ macronutrients are quickly taken up and utilized by the tissues of the plants by catalyzing effect of micronutrients/minor elements (Phillips, 2004). Micronutrients specially required by fruits crop for quality improvement. Foliar application of boron resulted in improving the yield and fruit quality of mango fruit in terms of weight, length and chemical parameters such as TSS, total sugars, ascorbic acid and total carotenoids (Singh et al., 2013).

\section{Materials and Methods}

The experiment was laid out in RBD (Randomized Block Design) with 10 treatments and 3 replications during the years 2015-2016. The 10 treatments consisting of recommended dose of fertilizer, macro (primary nutrients), micronutrient and their combinations were selected to see the effect on yield and quality of mango cv. Dashehari. The treatments consists of $\mathrm{T}_{1}$ : Control (RDF), $\mathrm{T}_{2}: \mathrm{RDF}+\mathrm{ZnSO}_{4} @ 200 \mathrm{~g}+$ Boric acid @ $100 \mathrm{~g}$ (soil application) in basin after harvest, $\mathrm{T}_{3}: \mathrm{RDF}+\mathrm{ZnSO}_{4} @ 200 \mathrm{~g}+\mathrm{CuSO}_{4} @ 100 \mathrm{~g}$ + Boric acid@100 g (soil application) in basin after harvest, $\mathrm{T}_{4}: \mathrm{RDF}+$ Foliar spray of $\mathrm{ZnSO}_{4} @ 0.4 \%+$ Boric acid @0.2\% (2 sprays at just before flowering and marble stage), $\mathrm{T}_{5}: \mathrm{RDF}+$ Foliar spray of $\mathrm{ZnSO}_{4} @$ $0.4 \%+\mathrm{CuSO}_{4} @ 0.2 \%+$ Boric acid @ 0.2 $\%$ (2 sprays at just before flowering and marble stage), $\mathrm{T}_{6}: \mathrm{RDF}+\mathrm{ZnSO}_{4} @ 100 \mathrm{~g}+$ $\mathrm{CuSO}_{4} @ 50 \mathrm{~g}+$ Boric acid @ $50 \mathrm{~g}$ (soil application)+Foliar spray of $\mathrm{ZnSO}_{4} @ 0.2 \%$ + Boric acid@0.1\% (2 sprays at just before flowering and marble stage), $\mathrm{T}_{7}: \mathrm{RDF}+$ $\mathrm{ZnSO}_{4} @ 100 \mathrm{~g}+\mathrm{CuSO}_{4} @ 50 \mathrm{~g}+$ Boric acid@50 g (soil application) + Foliar spray of $\mathrm{ZnSO}_{4} @ 0.2 \%+\mathrm{CuSO}_{4} @ 0.1 \%+$ Boric acid @ $0.1 \%$ (2 sprays at just before flowering and marble stage), $\mathrm{T}_{8}: \mathrm{RDF}+\mathrm{IIHR}$ Mango Special @ $5 \mathrm{~g} / \mathrm{l}$ (2 sprays at two months before flowering and marble stage), $\mathrm{T}_{9}: \mathrm{RDF}+\mathrm{NPK}:$ 20:20:20 @ $1 \%$ (2 spray: first- 15 days and Second - 45 days after fruit set) + $\mathrm{ZnSO}_{4} @ 200 \mathrm{~g}+$ Borax @ 100g + $\mathrm{CuSO}_{4} @ 100 \mathrm{~g}$ (Soil application) in basin after harvest, $\mathrm{T}_{10}: \mathrm{RDF}+\mathrm{NPK}: 20: 20: 20$ @ 1\% (2 Spray: first-15 days and Second- 45 days after fruit set) + foliar spray of $\mathrm{ZnSO}_{4} @$ $0.4 \%$ + Boric acid @ 0.2\% + $\mathrm{CuSO}_{4} @ 0.2 \%$ (2 Spray at just before flowering and marble stage). The yield was recorded in last week of June and it was expressed in tonnes $\mathrm{ha}^{-1}$. The various physico-chemical parameters were noted after harvesting of fruits. The fruit 
weight was recorded with the help of electronic top pan balance, fruit length and fruit width were measured with the help of digital Vernier Callipers, total soluble solids (TSS) content of mango was measured by the Hand Refrectometer $\left(0-30{ }^{0} \mathrm{~B}\right)$, titratable acidity and total sugar were estimated as per standard procedure suggested by A.O.A.C (1980). The ascorbic acid and total carotenoids content present in fruit juice was determined by the method as suggested by (A.O.A.C., 1960) and expressed as $\mathrm{mg} 100 \mathrm{~g}^{-1}$ pulp. The data were analysed according to the procedure of analysis for Randomized Block Design as explained by Cochran and Cox (1983). The mean values for all parameters were calculated and analysis of variances (ANOVA) for the characters was accomplished by F-variance test.

\section{Results and Discussion}

It is evident from Figure 1 that application of foliar application macro and micronutrients along with soil application of RDF (1000 g N: $750 \mathrm{~g} \mathrm{P}: 1000 \mathrm{~g} \mathrm{~K}$ ) showed a significant influence on yield in tonnes per hectare, yield efficiency and per cent increase in yield over control. The significant variation was also found with respect to fruit yield tonnes hectare $^{-1}$ and it was ranged from 7.60 to 22.82 tonnes hectare $^{-1}$. The maximum fruit yield per hectare (22.82 tonnes hectare $\left.{ }^{-1}\right)$ was recorded with the application of $\mathrm{T}_{10}[\mathrm{RDF}+\mathrm{NPK}$ : 20:20:20@1\% (2 spray : first-15 days and second 45 days after fruit set) $+\mathrm{ZnSO}_{4} @ 0.4$ $\%+$ Boric acid @ $0.2 \%+\mathrm{CuSO}_{4} @ 0.2 \%$ (2 spray at just before flowering and marble stage)], which was found statistically at par with $\mathrm{T}_{9} \quad\left(18.72\right.$ tonnes hectare $\left.{ }^{-1}\right)$. The minimum fruit yield (7.60 tonnes hectare ${ }^{-1}$ ) was obtained with the application of $T_{1}$ [Control (RDF)]. The per cent increase in yield showed the significant variations with application of different treatments. The data illustrated that the maximum per cent increase in yield over control was showed in $\mathrm{T}_{10}$ (197.41\%) treatment followed by $\mathrm{T}_{9}(143.93$ $\%)$ and $\mathrm{T}_{7}(116.54 \%)$, whereas, minimum per cent increase in yield was found in $\mathrm{T}_{2}(19.56$ $\%$ ) over the control. The data showed that the yield efficiency was affected significantly, which were ranged from 0.16 to $0.53 \mathrm{~kg} \mathrm{~m}^{-3}$. The maximum yield efficiency $\left(0.53 \mathrm{~kg} \mathrm{~m}^{-3}\right)$ was obtained with the application of $\mathrm{T}_{10}$ [RDF + NPK: 20:20:20 @ $1 \%$ (2 spray: first-15 days and second 45 days after fruit set) + $\mathrm{ZnSO}_{4} @ 0.4 \%+$ + Boric acid @0.2\%+ $\mathrm{CuSO}_{4} @ 0.2 \%$ (2 spray at just before flowering and marble stage)], which was found statistically at par with $\mathrm{T}_{9}\left(0.46 \mathrm{~kg} \mathrm{~m}^{-3}\right)$. The minimum yield efficiency $\left(0.16 \mathrm{~kg} \mathrm{~m}^{-3}\right)$ was obtained with the application of $\mathrm{T}_{1}$ [Control RDF] which was found statistically at par with $\mathrm{T}_{2}\left(0.16 \mathrm{~kg} \mathrm{~m}^{-3}\right), \mathrm{T}_{3}\left(0.18 \mathrm{~kg} \mathrm{~m}^{-3}\right)$ and $\mathrm{T}_{4}\left(0.21 \mathrm{~kg} \mathrm{~m}^{-3}\right)$. All the micronutrients when applied alone or in combination of macronutrients involved directly in physiological processes and enzymatic activity. This might have resulted into better photosynthesis, greater accumulation of starch in the fruits. The significant increase in fruit yield is a cumulative effect of increase in number of fruits because of reduction in fruit drop and also might be due to foliar application of macro and micronutrient including RDF that may influence the physiological processes resulting into higher fruit set and production of mango. Similar results were observed by Bhatt et al., (2012) in mango, Singh et al., (2003), Negi et al., (2010) in mango, Gurjar et al., (2015) in mango and Haldankar et al., (2012) in kokum.

The per cent increase in yield showed the significant variations with application of different treatments. The data illustrated that the maximum per cent increase in yield over control was showed in $\mathrm{T}_{10}(197.41 \%)$ treatment followed by $\mathrm{T}_{9}(143.93 \%)$ and $\mathrm{T}_{7}$ (116.54 \%), whereas, minimum per cent increase in yield was found in $\mathrm{T}_{2}(19.56 \%)$ 
over the control. The data showed that the yield efficiency was affected significantly, which were ranged from 0.16 to $0.53 \mathrm{~kg} \mathrm{~m}^{-3}$. The maximum yield efficiency $\left(0.53 \mathrm{~kg} \mathrm{~m}^{-3}\right)$ was obtained with the application of $\mathrm{T}_{10}[\mathrm{RDF}$ + NPK: 20:20:20 @ 1\% (2 spray : first-15 days and second 45 days after fruit set) + $\mathrm{ZnSO}_{4} @ 0.4 \%+$ + Boric acid @0.2\%+ $\mathrm{CuSO}_{4} @ 0.2 \%$ (2 spray at just before flowering and marble stage)], which was found statistically at par with $\mathrm{T}_{9}\left(0.46 \mathrm{~kg} \mathrm{~m}^{-3}\right)$. The minimum yield efficiency $\left(0.16 \mathrm{~kg} \mathrm{~m}^{-3}\right)$ was obtained with the application of $T_{1}$ [Control RDF)] which was found statistically at par with $\mathrm{T}_{2}\left(0.16 \mathrm{~kg} \mathrm{~m}^{-3}\right), \mathrm{T}_{3}\left(0.18 \mathrm{~kg} \mathrm{~m}^{-3}\right)$ and $\mathrm{T}_{4}\left(0.21 \mathrm{~kg} \mathrm{~m}^{-3}\right)$. All the micronutrients when applied alone or in combination of macronutrients involved directly in physiological processes and enzymatic activity. This might have resulted into better photosynthesis, greater accumulation of starch in the fruits. The significant increase in fruit yield is a cumulative effect of increase in number of fruits because of reduction in fruit drop and also might be due to foliar application of macro and micronutrient including $\mathrm{RDF}$ that may influence the physiological processes resulting into higher fruit set and production of mango. Similar results were observed by Bhatt et al., (2012) in mango, Singh et al., (2003), Negi et al., (2010) in mango, Gurjar et al., (2015) in mango and Haldankar et al., (2012) in kokum.

Table.1 Effect of soil and foliar application of macro and micronutrients on physico - chemical quality parameters of mango cv. Dashehari

\begin{tabular}{|c|c|c|c|c|c|c|c|c|}
\hline & \multicolumn{3}{|c|}{ Physical parameters } & \multicolumn{5}{|c|}{ Chemical parameters } \\
\hline $\begin{array}{c}\text { Treatments } \\
\#\end{array}$ & $\begin{array}{c}\text { Fruit } \\
\text { weight } \\
\text { (g) }\end{array}$ & $\begin{array}{c}\text { Fruit } \\
\text { length } \\
(\mathrm{cm})\end{array}$ & $\begin{array}{r}\text { Fruit } \\
\text { width } \\
\text { (cm) }\end{array}$ & $\begin{array}{c}\text { Total } \\
\text { sugar } \\
(\%)\end{array}$ & $\begin{array}{l}\text { TSS } \\
\left({ }^{\circ} \mathrm{B}\right)\end{array}$ & $\begin{array}{c}\text { Titratable } \\
\text { acidity } \\
(\%)\end{array}$ & $\begin{array}{c}\text { Ascorbic } \\
\text { acid (mg } \\
100 \mathrm{~g}^{-1} \\
\text { pulp) }\end{array}$ & $\begin{array}{c}\text { Total } \\
\text { carotenoids } \\
\text { content (mg } \\
100 \mathrm{~g}^{-1} \text { pulp) }\end{array}$ \\
\hline $\mathrm{T}_{1}$ & 105.00 & 7.90 & 4.82 & 10.80 & 16.25 & 0.146 & 34.45 & 8.14 \\
\hline $\mathrm{T}_{2}$ & 125.20 & 8.20 & 4.92 & 11.10 & 16.40 & 0.180 & 36.15 & 9.25 \\
\hline $\mathrm{T}_{3}$ & 136.10 & 8.95 & 5.02 & 11.81 & 16.76 & 0.166 & 37.35 & 10.02 \\
\hline $\mathrm{T}_{4}$ & 178.94 & 9.54 & 5.19 & 12.80 & 18.02 & 0.190 & 42.60 & 11.04 \\
\hline $\mathrm{T}_{5}$ & 198.26 & 10.40 & 5.37 & 13.66 & 18.45 & 0.166 & 46.03 & 11.05 \\
\hline $\mathrm{T}_{6}$ & 195.30 & 10.58 & 5.34 & 14.85 & 18.26 & 0.250 & 44.23 & 11.56 \\
\hline $\mathrm{T}_{7}$ & 212.00 & 10.48 & 5.40 & 15.10 & 17.50 & 0.193 & 46.30 & 11.84 \\
\hline $\mathrm{T}_{8}$ & 191.58 & 10.59 & 5.49 & 13.70 & 18.75 & 0.150 & 48.40 & 11.77 \\
\hline $\mathrm{T}_{9}$ & 216.41 & 10.67 & 5.47 & 13.90 & 18.83 & 0.133 & 46.29 & 10.53 \\
\hline $\mathrm{T}_{10}$ & 254.60 & 10.86 & 5.65 & 15.38 & 19.18 & 0.116 & 48.47 & 12.08 \\
\hline SEm \pm & 18.24 & 0.47 & 0.15 & 0.05 & 0.16 & 0.019 & 0.44 & 0.38 \\
\hline CD $(5 \%)$ & 54.20 & 1.40 & 0.46 & 0.17 & 0.50 & 0.058 & 1.31 & 1.15 \\
\hline
\end{tabular}


Fig.1 Effect of soil and foliar application of macro and micronutrients nutrients on yield, per cent increase in yield over control and yield efficiency of mango cv. Dashehari

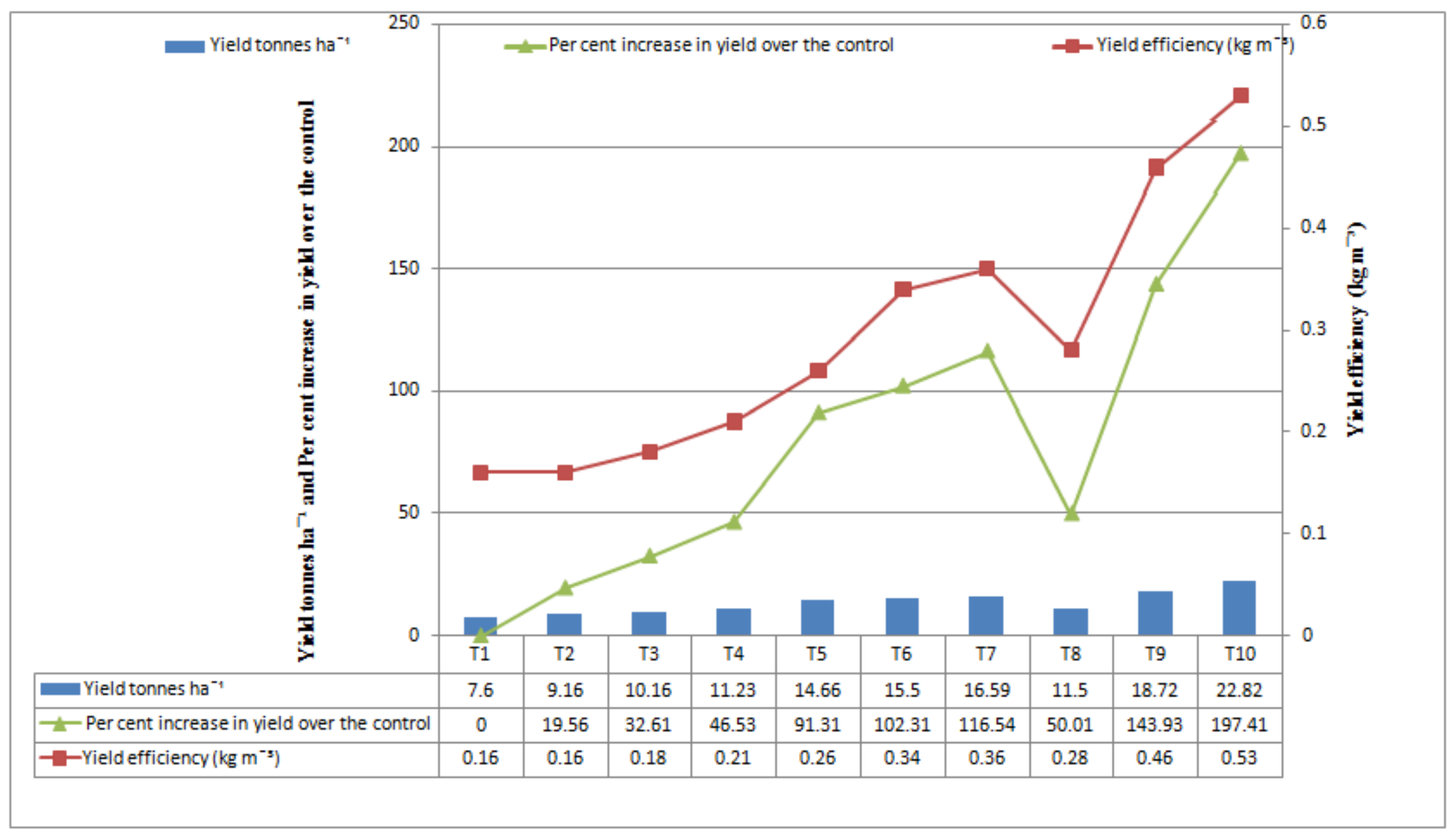


The data presented in Table 1 showed that significant variation observed in physicochemical quality attributes with the application of different treatments. The data revealed that among all the treatments, the highest T.S.S $\left(19.18^{\circ} \mathrm{B}\right)$ was observed in $\mathrm{T}_{10}$ [RDF + NPK : 20:20:20 @ 1 \% (2 spray : first-15 days and second 45 days after fruit set)+ $\mathrm{ZnSO}_{4} @ 0.4 \%+$ Boric acid @ $0.2 \%$ $+\mathrm{CuSO}_{4} @ 0.2 \%$ (2 spray at just before flowering and marble stage)], which was found statistically at par with $\mathrm{T}_{9}\left(18.83{ }^{\circ} \mathrm{B}\right)$ and $\mathrm{T}_{8}\left(18.75^{\circ} \mathrm{B}\right)$ however, the lower content $\left(16.25^{\circ} \mathrm{B}\right)$ of total soluble solids (T.S.S) was found in $\mathrm{T}_{1}$ [Control RDF)], which was found statistically at par with $\mathrm{T}_{2}\left(16.40{ }^{\circ} \mathrm{B}\right)$. The maximum titratable acidity was observed in $\mathrm{T}_{6}$ $(0.25 \%)$ whereas, minimum acidity $(0.11 \%)$ was observed in $\mathrm{T}_{10}$. The higher total sugar content $(15.38 \%)$ was recorded in $\mathrm{T}_{10}$ followed by $\mathrm{T}_{7}(15.10 \%)$ whereas, the lower total sugar content $(10.80 \%)$ was observed in $\mathrm{T}_{1}$ [Control (RDF)] followed by $\mathrm{T}_{2}(11.10 \%)$. The ascorbic acid content varied from 34.45

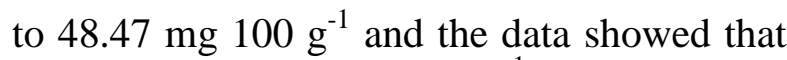
maximum (48.47 mg $100 \mathrm{~g}^{-1}$ ) ascorbic acid was obtained with $\mathrm{T}_{10}$, which was found statistically at par with $\mathrm{T}_{8}\left(48.40 \mathrm{mg} 100 \mathrm{~g}^{-1}\right)$. The minimum ascorbic acid content (34.45 $\mathrm{mg} 100 \mathrm{~g}^{-1}$ ) was recorded with of $\mathrm{T}_{1}$ [control (RDF)] followed by $\mathrm{T}_{2}\left(36.15 \mathrm{mg} 100 \mathrm{~g}^{-1}\right)$ and $\mathrm{T}_{3}\left(37.35 \mathrm{mg} 100 \mathrm{~g}^{-1}\right)$. The mean value for total carotenoids range from 8.14 to $12.08 \mathrm{mg}$ $100 \mathrm{~g}^{-1}$, the maximum total carotenoids content (12.08 mg $\left.100 \mathrm{~g}^{-1}\right)$ was observed in $\mathrm{T}_{10}$ which was found statistically at par with $\mathrm{T}_{8}, \mathrm{~T}_{7}, \mathrm{~T}_{6}, \mathrm{~T}_{5}$ and $\mathrm{T}_{4}$ whereas, the minimum total carotenoids content (8.14 mg $100 \mathrm{~g}^{-1}$ ) was found in $T_{1}$ [control (RDF)]. The increase in ascorbic acid might be due to higher level of sugars in boron treated fruit along with foliar application of macronutrients, which increased the content of ascorbic acid, since ascorbic acid is synthesized from sugar. Similar result was observed by Singh et al., (2013) in mango, Singh et al., (2003) in mango and Kashyap et al., (2012) in pomegranate. The improvement in yield and quality of fruit could be due to the catalytic action of micronutrients. The foliar application of micronutrients quickly increases the uptake of macronutrients in the tissues and organs of the plant and decreases the nutritional deficiencies that finally lead to improvement in the fruit yield and quality.

On the basis of results, it may be concluded that the application of RDF (1000 g N: $750 \mathrm{~g}$ P: 1000 g K) + NPK : 20:20:20@ $1 \%$ (2 spray : first-15 days and second 45 days after fruit set) + foliar spray of $\mathrm{ZnSO}_{4} @ 0.4 \%$ + Boric acid@0.2\%+. $0.2 S_{4} @ 0.2 \%$ (2 spray at just before flowering and marble stage) was found most effective for increasing the yield ha- ${ }^{-1}$ (22.82 tonnes), increase in yield over control (197.41\%), yield efficiency $\left(0.53 \mathrm{~kg}^{-3}\right)$ and the physico-chemical quality parameters such as fruit weight $(254.60 \mathrm{~g})$, fruit length $(10.86 \mathrm{~cm})$, fruit width $(5.65 \mathrm{~cm})$, higher TSS $\left(19.18{ }^{\circ} \mathrm{B}\right)$, total sugar $(15.38 \%)$, total carotenoids content $\left(12.08 \mathrm{mg} 100 \mathrm{~g}^{-1}\right.$ pulp) and ascorbic acid (48.47 mg $100 \mathrm{~g}^{-1}$ pulp).

\section{References}

A.O.A.C. 1960. Official Methods of Analysis. Association of Official Analytical Chemist, Benjaminn Franklin Station, Washing ton, D.C., USA.

A.O.A.C. 1980. Official Methods of Analysis. Association of Official Analytical Chemist, Benjaminn Franklin Station, Washing ton, D.C., USA.

Anonymous, 2015. Horticultural Statistics at a Glance. National Horticulture Board, Gurgaon, Haryana.

Bhatt, A., Mishra, N.K., Mishra, D.S. and Singh, C.P. 2012. Foliar application of potassium, calcium, zinc and boron enhanced yield, quality and shelf life of mango. Hort. Flora Research Spectrum, 
1(4): 300-305.

Cochran, W., and Cox, G.M. 1983. Experimental Design, Asia Publishing House, Bombay, pp. 143-147.

De-Candole, A.D.E., 1984. Origin of Cultivated Plants. Vegal Paul Trench and Company, London. pp. 1-67.

Gurjar, T.D., Patel, N.L., Panchal, B. and Chaudhari, D. 2015. Effect of foliar spray of micronutrients on flowering and fruiting of Alphonso mango. The bioscan, 10(3): 1053-1056.

Haldankar, P.M., and Somavanshi, A.V. 2012. Studies on the effect of foliar sprays of nutrients after fruit set on harvesting, yield and quality of kokum (Garcinia indica Choisy). Indian J. Hort., 72(1): 38-42.

Hill, A.F., 1952. Economic Botany edn. 2 Mc Graw-Hill \& Kogakusha.

Iyer, C.P.A., and Degani, C. 1997. Classical breeding and genetics. In: Litz RE, editor. The Mango: Botany, Production and Uses. Wallingford Oxon/CAB International, pp. 49- 68.

Kashyap, P., Pramanick, K.K., Meena, K.K. and Meena, V. 2012. Effect of N and K application on yield and quality of pomegranate $\mathrm{cv}$. Ganesh under rainfed conditions. Indian J. Hort., 69(3): 322327

Kostermans, A.J.G.H., and Bompard, J.M. 1993. The Mango: Their Botany,
Nomenclature: Horticulture and Utilization, pp. 232. International Board for Plant Genetic Resources Rome and the Lincann Society of London, Academic Press, Harcourt Brace and Company, Publishers, London.

Negi, S. S., Singh, A.K. and Rai, P.N 2010. Effect of foliar application of nutrients on pollen, flowering, fruit set, fruit drop and yield in mango cultivar Dashehari. The Hort. J., 23(2): 45-48.

Phillips, M., 2004. Economic benefits from using micronutrients for the farmer and the fertilizer producer. International symposium on micronutrients. New Delhi, India. pp. 23-25.

Popenoe, W., 1920. Manual of Tropical and Subtropical Fruits. Mc Millan, New York, pp.79-160 (facsimile of the 1920 edn. 1974) Hafner Press, New York.

Singh, A.K., Singh, C.P., Lal, Shant and Pratibha 2013. Effect of micronutrients and sorbitol on fruit set, yield and quality of mango cv. Dashehari. Prog. Hort., 45(1): 43-48.

Singh, J., and Maurya, A.N. 2003. Effect of micronutrients on quality of fruits of mango (Mangifera indica L.) cv. Mallika. Prog. Agri., 3(1 \& 2): 92-94.

Vavilov, N.I., 1926. The origin, variation, immunity and breeding of cultivated plants. Chronica Botanica, 13(16): 1949-1950.

\section{How to cite this article:}

Pankaj Kumar, A.K. Singh and Shankhdhar, S.C. 2017. Efficacy of Soil and Foliar Application of Macro and Micronutrients on Yield and Quality of Mango cv. 'Dashehari'. Int.J.Curr.Microbiol.App.Sci. 6(10): 1855-1861. doi: https://doi.org/10.20546/ijcmas.2017.610.224 